\begin{tabular}{|c|c|c|c|}
\hline Article Info & RESEARCH ARTICLE & ARAŞTIRMA MAKALESİ & \\
\hline Title of Article & \multicolumn{2}{|c|}{$\begin{array}{c}\text { Evaluation of Historical Layers In The } \\
\text { Context Of Spatial Continuity : The Case Of } \\
\text { Antakya }\end{array}$} & 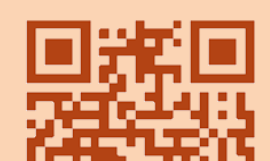 \\
\hline $\begin{array}{l}\text { Corresponding } \\
\text { Author }\end{array}$ & \multicolumn{2}{|c|}{$\begin{array}{l}\text { Şen YÜKSEL } \\
\text { Beykent Üniversitesi/Mühendislik ve Mimarlık Fakültesi/İç Mimarlık (TR) Bölümü, } \\
\text { senyuksel@beykent.edu.tr }\end{array}$} & \\
\hline $\begin{array}{l}\text { Received Date } \\
\text { Accepted Date }\end{array}$ & \multicolumn{2}{|c|}{$\begin{array}{l}09.05 .2021 \\
30.05 .2021\end{array}$} & \\
\hline DOI Number & \multicolumn{2}{|l|}{ https://doi.org/10.35674/kent.935168 } & \\
\hline Author / Authors & Şen YÜKSEL & ORCID: 0000-0002-0827-3930 & \\
\hline How to Cite & \multicolumn{2}{|c|}{$\begin{array}{l}\text { YÜKSEL, Ş. (2021). Mekansal Süreklilik Bağlamında Tarihsel Katmanların } \\
\text { Değerlendirilmesi : Antakya Kenti Örneği, Kent Akademisi, Volume, 14, Issue 2, Pages, } \\
\text { 361-373 }\end{array}$} & $\begin{array}{l}\text { Kent Akademisi } \\
\text { Urban Academy }\end{array}$ \\
\hline
\end{tabular}

\title{
Mekansal Süreklilik Bağlamında Tarihsel Katmanların Değerlendirilmesi : Antakya Kenti Örneği
}

\begin{abstract}
:
Our country is very rich in terms of cities with historical layers; however, their numbers are gradually decreasing. It is very important for the continuity of societies to pass on historical values to future generations without deterioration. The common points and the differences between the layers are provide this continuity. Antakya is one of the few cities that has strong identity elements belonging to different layers and continues its development by preserving its historical value. In this study, different layers of the city were analyzed and compared in urban and architectural scales, in order to preserve the cultural continuity; and historical common points and differences in the city were tried to be determined. The study aims to make a reference to the future growth of the city by determining the reasons why and how those common points took place and under which conditions. For this purpose; The city in the Roman Period was examined on an urban scale. Important buildings were mentioned and highlighted where the Roman period villas, in order to focus on the residential fabric of the settlement in more detail, were examined on a plan basis, in architectural scale. Similarly, The Ottoman Period of the city was also examined on an urban and architectural scale, and common features were revealed in the context of the city plan and residences. The current situation of the city of Antakya, on the other hand, has not been investigated in the same detailed manner since it does not reflect the historical and local characteristics of the city that are mentioned previously, to that extent. As a result, the urban and architectural characteristics of the historical layers of the city are both determined and compared. The evaluation of the data obtained through focusing on the architectural common and differing points of those layers, belonging to different cultures in the history, determined and act as a reference to guide future designs.
\end{abstract}

Keywords: Antakya, identity, cultural continuity, historical layers, environmental conditions.

\footnotetext{
${ }^{1}$ Assoc.Prof., Beykent University, Faculty of Engineering and Architecture, Department of Interior Architecture, senyuksel@ beykent.edu.tr
} 


\section{ÖZ:}

Ülkemiz tarihi katmanlara sahip kentler bakımından oldukça zengindir, ancak bu yerel kentlerin sayısı giderek azalmaktadır. Tarihi değerlerin gelecek nesillere bozulmadan aktarılması, toplumların sürekliliği için oldukça önemlidir. Katmanlar arasındaki ortaklıklar veya farklılıklar, bu sürekliliği sağlar. Antakya, farklı katmanlara ait güçlü kimlik ögelerine sahip, günümüze kadar tarihi değerini koruyarak gelişimini sürdüren, az sayıdaki kentlerimizden biridir. Çalışmada; kültürel sürekliliği korumaya yönelik olarak, kentin farklı katmanları, kentsel ve yapısal ölçekte incelenerek karşılaştırılmış, kentteki tarihsel ortaklıklar ve farklılıklar belirlenmeye çalışılmıştır. Ortaklıkların nedeni ve nasıl gerçekleştiği, hangi koşullarda nasıl tavır alındığı belirlenerek, kentin yeni oluşumuna referanslar çıkarılması amaçlanmıştır. Geçmişin aynısını tekrar etmek değil neden ve nasıl sorularıyla, felsefesini ortaya koyarak yararlanmak çalışmanın hedefi olmuştur. Bu amaca yönelik olarak; kentin Roma Dönemindeki durumu, kent ölçeğinde ele alınmış, önemli yapılar üzerinde durulmuş, konut dokusuna ağırlık verilerek Roma dönemi villaları plan bazında incelenmiştir. Kentin Osmanlı Dönemi de yine kentsel ve yapısal ölçekte incelenmiş, kent planı ve konutlar bağlamında ortak özellikleri ortaya konulmuştur. Antakya kentinin günümüzdeki durumu ise, kentin tarihi ve yerel özelliklerini içermemesi nedeniyle diğer dönemlerdeki kadar detaylı ele alınmamıştır. Sonuçta, kentin tarihsel katmanlara ait kentsel ve yapısal özellikleri belirlenmiş ve katmanlar bazında karşılaştırılmıştır. Elde edilen veriler değerlendirilerek, tarihsel süreçte farklı kültürlerin kentteki mimari ortaklıkları ve farklılıkları belirlenmiş yeni tasarımlara referanslar çıkarılmıştır.

Anahtar Kelimeler: Antakya, kimlik, kültürel süreklilik, tarihsel katmanlar, çevresel koşullar

\section{"Mekansal Süreklilik Bağlamında Tarihsel Katmanların Değerlendirilmesi: Antakya Kenti Örneği”"}

\section{GíRiș:}

Toplumların kendi kültürlerini oluşturduğu ve yaşattığı yerleşimler, o yerin çevresel özellikleri doğrultusunda biçimlenirler. Doğal Çevre koşulları denilen iklimsel ve coğrafi etmenler ile sosyal çevrenin, her yerde aynı özellikleri göstermemesi, değiş̧ik bölgelerin ortaya çıkmasına neden olmuştur. Kentlerin oluşumunda önemli yere sahip olan çevresel özelliklerin farklı olması nedeniyle de farklı kimlik ve özelliklere sahip kentler ortaya çıkmıştır. Yerel özellikler taşıyan bu kentler, tarihsel süreçte çeşitli kültürlerin etkisinde kalarak değişim ve gelişimlerini sürdürmüşlerdir. Farklı dönemlerin bir sentezi olarak günümüze kadar gelen kentler, toplumların kültürlerini, fiziksel değerler bağlamında ve tarihsel süreklilik içinde ortaya koyduğu mekanlardır. Toplumların gelecek yüzyıllarda var olabilmelerini amaçlayan sürdürülebilirlik kavramı, kentlerin kimlik ve kültürel özelliklerini kaybetmeden gelişmeleriyle gerçekleşebilir. Ancak teknolojik gelişmeler ve iletişimin yayılması sonucunda, kentler giderek kimlik ve özelliklerini kaybetmeye başlamışlardır. Çevresel koşullar ve kültür göz ardı edilerek ortaya çıkan yeni yerleşimler, o bölgenin özgün mimarisi olmaktan uzaklaşmaktadır. Bölgenin fiziksel ve toplumsal gereksinimlerine cevap vermeyen, birbirinin benzeri binalar inşa edilmeye başlanınca, her bölgede hatta her ülkede uygulanabilen, kimliksiz, bağlamı olmayan 'yer'siz yapılar ortaya çıkmaktadır. Fiziksel ve kültürel değerler gözardı edilerek, referansı olmadan yapılan binalar, kentin giderek kimliksizleşmesine neden olmaktadır. Kontrolsüz büyüme, kimlik ve toplumsal belleğin kaybolmasına yol açarken, tarihi değeri olan yapıların da bozulmasına yol açmaktadır. Değişim kaçınılmazdır ancak kentlerdeki her değişim, fiziksel ve kültürel kimlik sürekliliğini sağlayacak şekilde olmalıdır (Massey, 2001)(Ballantyne, 2014)(Norberg, 1984). Farklı dönemlere ait kalıntı ve izlerin yatayda, düşeyde veya farklı açılarda dizildiği yerleşimlere çok katmanlı kent denilmektedir. Tarihsel süreçte farklı kültürlere tanıklık etmiş kentlerin tarihi katmanlarındaki bu izler, kentin kültürü ve kimliği hakkında bilgi içerirler. Kentin sürekliliği, bu katmanların okunması ve değerlendirilmesi ile sağlanabilir. Farklı katmanlardaki mekanların benzer kodlarla tasarlanmış olması, mekânsal sürekliliği sağlayan kriterlerdir. Geçmiş ve gelecek arasında kurulacak ilişkiler, sürekliliği sağlarken, tarihi geçmişi güçlü kentlerde yeni tasarımlara da veri sağlarlar (Gür, 2017)(Çalışır, 2009)(Apaydın, 2019).

Antakya Kenti, M.Ö.300 yıllarına kadar giden tarihi ve çok katmanlı bir kenttir. Güçlü kimlik ve kültürel ögelere sahip olan kent, her dönem siyasi, dini ve ekonomik önemini korumuş, günümüze kadar da devam ettirmiştir. Ancak günümüzde birç̧ok kentte olduğu gibi Antakya'da da, kentsel ve mekânsal gelişim olumsuz yönde ilerlemekte, kimlik ve kültürel süreklilik kesintiye uğramaktadır. Hızlı ve kontrolsüz büyüme, kent ve kentliyle ilişki kuramayan, kimliksiz "yer"siz yapıların çoğalmasına ve yaşam kalitesinin düşmesine neden olmaktadır. Kentin mekânsal 
sürekliliğinin kaybolmasına neden olan bu değişim, kimlik ve kollektif belleğin kaybolmasının önüne geçilmesi ile durdurulabilir (Manning, 2020) (Tanyeli, 2017).

Çalışmada; kentin tarihi katmanları kentsel ve yapısal ölçekte incelenmiştir. Geçmişte en güçlü kimlik ögelerine sahip olan katmanlar ele alınmıştır. Amaç, kentin sürekliliğini sağlamak ve geçmişle gelecek arasında bağ kurabilmek için katmanlar arasındaki benzerlikleri ortaya çıkararak, veri elde edebilmektir. Bu amaca yönelik olarak, literatür taraması, gözlem gibi araştırma yöntemleri kullanılmıştır. Kentle ilgili yerli ve yabancı literatür araştırması detaylı olarak yapılmıştır. Görsel ve sözel kaynaklar elde edilmiştir. Çalışma, zaman sürecinde kente dair yapılan çeşitli araştırma, yazı ve gözlemlerin sonucunda ortaya çıkarılmıştır. Kentte önemli iz bırakmış olan katmanlardan, Roma ve 19. Yüzyıl Osmanlı Dönemi ele alınmıştır. Dönemler kentsel ve mimari kurgu bazında incelenmiş, benzerlik ve farklılıklar ortaya konmuştur. İnsanlığın en temel ihtiyaçlarından biri olan barınmanın tarihsel süreç içinde farklılıklar göstermesi nedeniyle çalışmada konutlar değerlendirilmiştir. Roma villaları ve Osmanlı avlulu konutları, plan ölçeğinde mekânsal ve yapısal olarak incelenmiş, benzerlikler belirlenmiştir. Dönemlere ait yapılarda benzer mekânsal özelliklerin görülmüş olması ; mekânsal sürekliliği sağlarken bağlamsal tutarlılı̆̆ı da göstermektedir. Fiziksel çevre koşullarına göre biçimlenen mimari birliktelikler değerlendirilerek yeni tasarımlara yönelik ipuçları çıarılmaya çalışılmıştır.

\section{Antakya Kenti}

Anadolu'nun güneyinde yer alan Antakya kenti, bugün hala izlerini görebildiğimiz çeşitli uygarlıkları bünyesinde barındırmıştır. Dünyanın en eski yerleşimlerinden biri olan kentin tarihi, paleolitik çağa kadar uzanmaktadır. Kent tarihsel sürecinde konumu nedeniyle dini, siyasi ve ekonomik bakımdan daima önemli bir merkez konumunda olmuştur. Helenistik Dünyanın merkezi haline gelen Antakya, Roma Döneminde Roma ve İskenderiye'den sonra üçüncü büyük kent haline gelmiştir. Farklı kültürlerin etkisi altında kalmış olan kent, doğal çevre, yapılı çevre ve sosyal çevreden kaynaklanan güçlü kentsel kimlik öğelerine sahiptir. Kentin ortasından geçen Asi nehri, endemik bitki örtüsü, iklimi, farklı dönemlerdeki mimarisi, tarihi eserleri ve hala yaşayan farklı dinlere mensup halkı önemli kimlik ögelerindendir. Antakya'da Müslüman, Hristiyan ve Yahudi toplumlar geçmişten günümüze kadar bir arada yaşamaktadır. İlk kilise olarak anılan St Pierre Kilisesi, hiristiyan dininin haç yeridir. Habib Neccar Camii, Anadolu' daki ilk camiidir. Bugün kentte, tarihin izlerini görmek mümkündür ancak yerleşmenin kimliğini oluşturan bu özelliklerin süreç içerisinde değerlendirilememesi, kent ve toplum açısından olumsuzluklara neden olmaktadır.

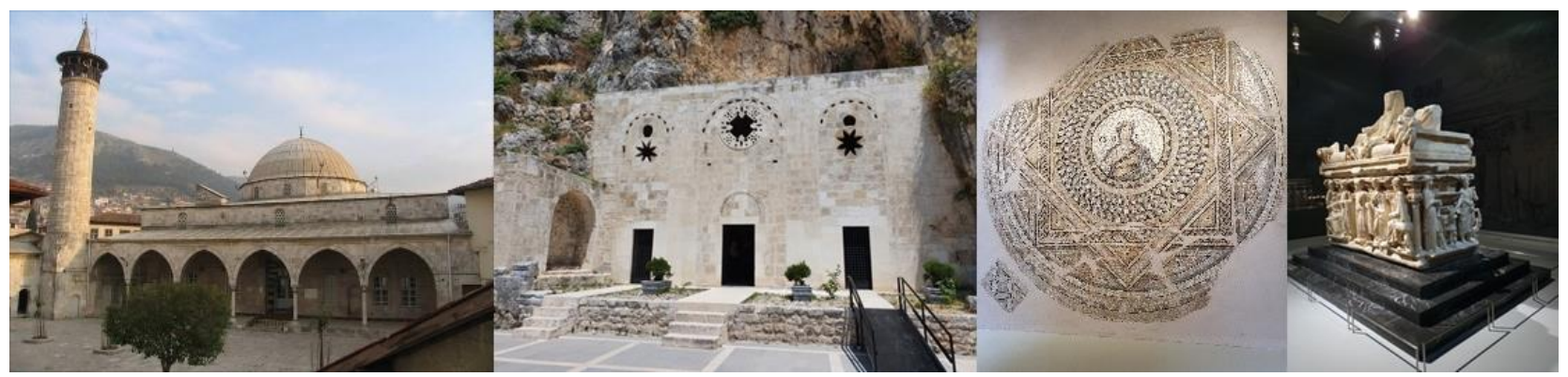

Şekil 1. Antakya, Habib Neccar Camii, St. Pierre Kilisesi, mozaikleri ve lahitleri ile kültür varlıkları açısından zengin bir kenttir. (Ş. Yüksel Arşivi) 
Tablo 1. Tarihsel süreç içinde Antakya farklı kültürlerin etkisi altında kalmştır.

\begin{tabular}{|c|c|c|}
\hline G.Ö. $\mathbf{4 3} \mathbf{0 0 0}$ - M.S. $\mathbf{3 3 3}$ & M.S. 333- M.S. 1516 & M.S. 1516-1918-1938-1939 $\rightarrow$ \\
\hline Paleolitik Çağ & Helenistik Dönem & Osmanlı Dönemi (1516-1918) \\
Epipaleolitik Çağ & Seleukos Krallığı & Fransılar Dönemi (1918-1938) \\
Neolitik Çağ & Roma Cumhuriyeti & Hatay Devleti (1938-1939) \\
Kalkolitik Çağ & Roma İmparatorluğu & Türkiye Cumhuriyeti (1939 $\rightarrow$ \\
Erken Tunç Çağı & Doğu Roma & \\
Orta Tunç Çağı & İlami Dönem & \\
Geç Tunç Çağı & Doğu Roma & \\
Demir Çağı & Selçuklu İmparatorluğu & \\
Arkaik Dönem & Antalya Haçlı Prensliği & \\
Klasik Dönem & Memluklar Dönemi & \\
\hline
\end{tabular}
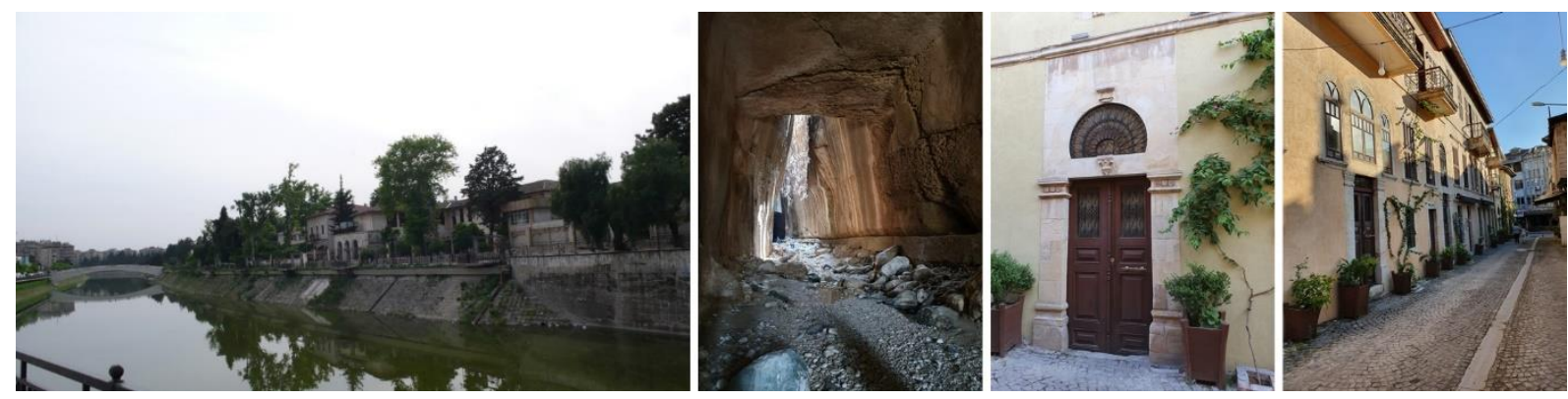

Şekil 2. Kentin ortasından geçen Asi nehri, endemik bitki örtüsü, iklimi, farklı dönemlerdeki mimarisi, tarihi eserleri ve birarada yaşayan farklı dinlere mensup halkı önemli kimlik ögelerindendir. (Ş.Yüksel Arşivi)

\section{Roma Dönemi’nde Antakya Kenti}

Tarihinde yangınlar ve depremler sonucu çeşitli defalar yeniden inşa edilen kent, Romalılar Döneminde altın çağını yaşamıştır. Roma İmparatorluğunun İskenderiye ve Roma'dan sonra 3. büyük kenti olan Antakya'da (Antiokheia) yapılan arkeolojik kazı çalışmalarında, Roma dönemine ait çok sayıda bazilika, hamam ve villalar bulunmuştur. Bugün hala devam eden kazılar mevcuttur. 1050 metrekare büyüklüğ̈unde dünyanın en büyük tek parça mozaiği, 2009 yılında bir otelin temel kazısı sırasında ortaya çıkarılmıştır. Roma İmparatorluğu'nun olimpiyatlar şehri olarak anılan kentteki hipodrom kazısı devam etmektedir. Hipodromun M.Ö. 67 yıllarına ait olduğu ve kentin eski çağlarda yaklaşık 400 yıl boyunca olimpiyatların düzenlendiği bir yer olduğu belirlenmiştir. Yarışmaların yapıldığı, $492.5 \mathrm{~m}$. ve en geniş orta bölümü 75 m uzunluğunda olan arenası ile bugüne kadar çıkartılan en büyük hipodromlardan biri olduğu ifade edilmektedir (Pamir,H. 2014).

\subsection{Roma Dönemi Kentsel Mekan Kurgusu}

Tarihi kent, Helenistik devirde, Asi (Orantes) nehrinin kenarında, Habib Neccar (Silpios) Dağı'nın eteklerinde, topoğrafyaya uyumlu olarak kurulmuştur. Seleukos döneminde kent, arka arkaya 4 semt ilave edilerek büyütülmüş, dördüncü semtin yapılmasıyla beraber kentin çevresi surlarla çevrilmiştir. Bugün bu sur kalıntılarını görmek mümkündür. Romalı yazarlara göre , kentin mimarı Xenarius' tur ve planlamasında Hippodamus'un ilkelerini uygulamıştır. Kent, uzun bir eksenin iki yanında birbirini dik açılarla kesen yapı adalarından oluşan izgara plan tipinde inşa edilmiştir (Şekil 3). Kentin sokakları sıcak nemli iklim bölgesine sahip olması nedeniyle hakim rüzgarı ve nehirden gelecek rüzgarı içine alacak şekilde, Asi nehrine dik olarak planlanmıştır. Çok yağış alması ve yağmur sularının bu sokaklardan nehre dökülmesi de kenti su baskınlarına karşı korumuştur. Kenti kuzeydoğu-güneybatı doğrultusunda kesen kolonadlı bir cadde (Herod caddesi) olduğu anlaşılmıştır (Kondoleon, 2000) (Demir, 1996). 
Asi nehrinin üzerindeki adada saraya ait yapılar, hamamlar olduğu bilinmekte ve günümüzde kazı çalışmaları yapılmaktadır. Bu alan, nehrin yatağının değiştirilmesiyle günümüzde ada konumunda değildir (Şekil 3).

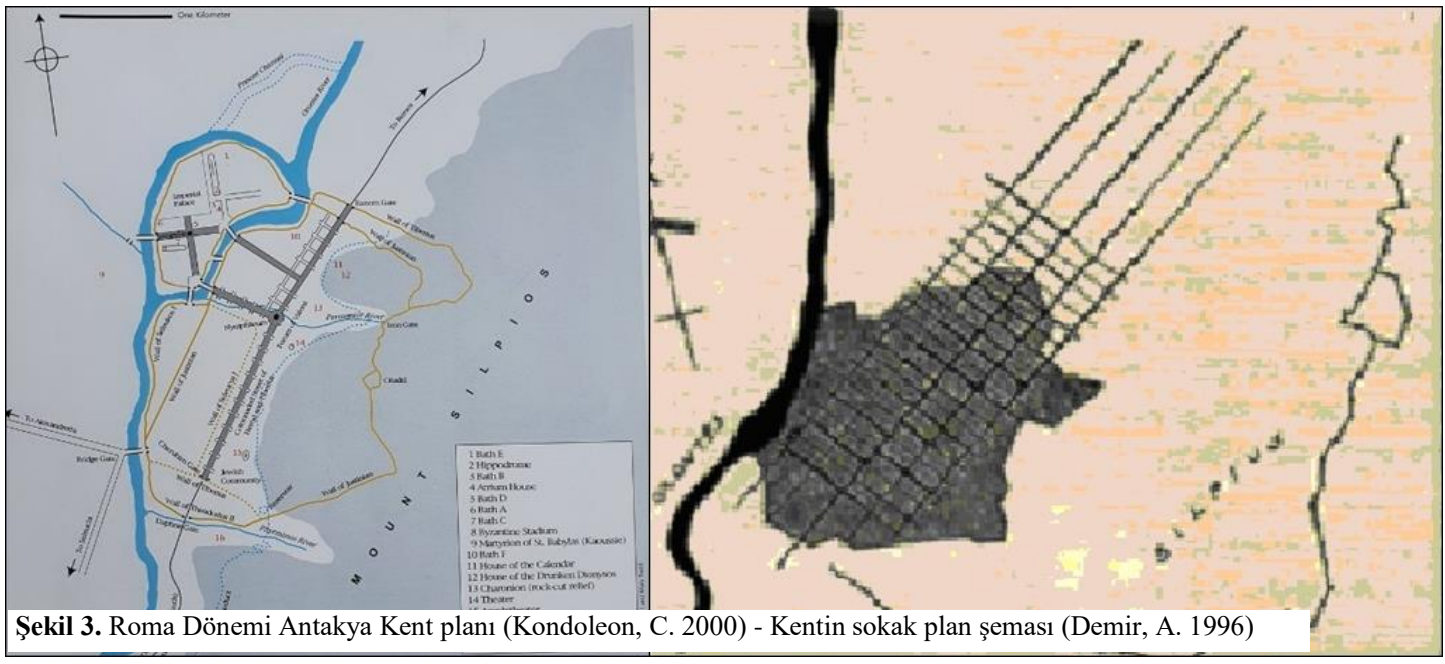

Roma döneminde kente su kemerleri ile Harbiye'den (Daphne) su getirilmiştir. Günümüzde su kemerleri ve hamamların kalıntıları kentte görülmektedir. Bu dönemde Asi nehri üzerinde bir köprü inşa edilmiş ancak, 1974 yılında, bu Roma Köprüsü yıkılarak yerine başka bir köprü inşa edilmiştir.

\subsection{Roma Dönemi Mimari Mekan Kurgusu}

Antakya kenti ve çevresinde, Roma dönemine ait çok sayıda mimari eser kalıntısı bulunmuştur. Kentin Harbiye (Daphne) bölgesindeki kazılarda, şelalelerin çevresinde, Roma villaları ortaya çıkarılmıştır. M.S. II ve M.S. IV. yüzyıllar arasında yapıldığı belirlenen evlerin çoğunun planları çizilebilmiş ve farklı dönemlerde ilaveler yapıldığı görülmüş̧ür. Evlerin döşeme ve duvarlarından çıkan mozaikler Antakya Müzesinde sergilenmektedir (Redford, 2014). Planı çizilen Roma evlerinin, mekansal kurgusu, yapı elemanları ve malzemeleri, çevre bağlamında değerlendirilmiştir.

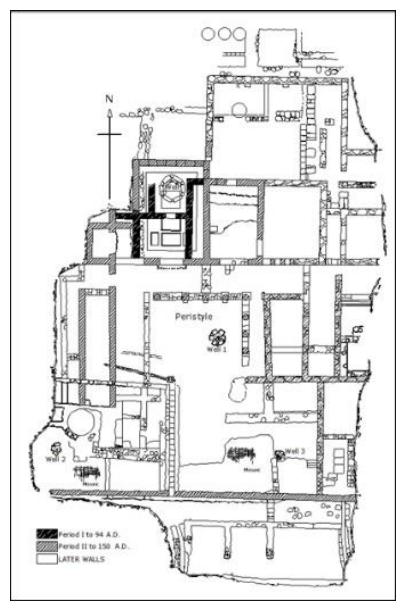

Sekil 4. 1 Numaralı Roma Evi Kalıntıs1 (Usman, 1958)
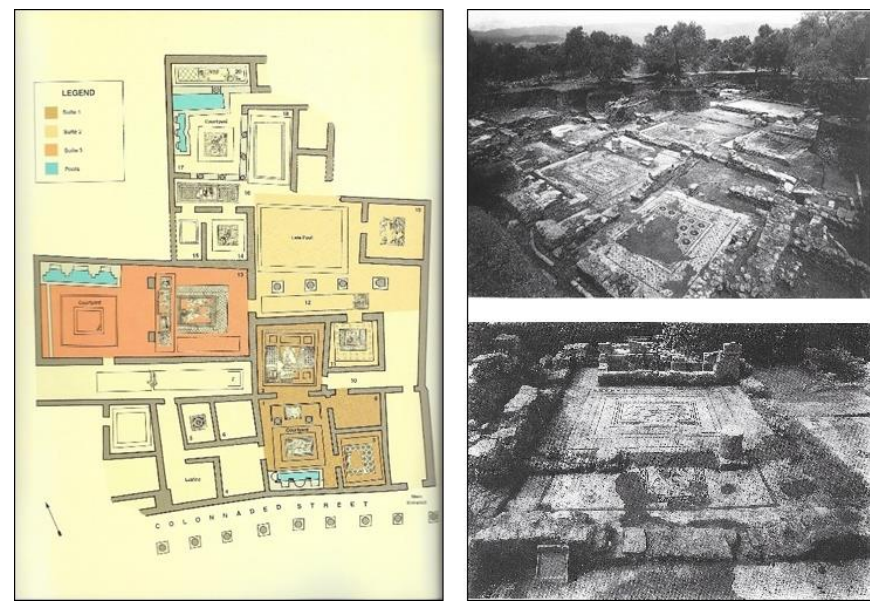

Şekil 5. 2 Numaralı Roma Evi, (Menander Evi) Plan Şeması ve Döşeme Mozaikleri (Kondoleon, 2001) (Usman, 1958)

1 numaralı Roma evi kalıntısı, Antakya kentinin güneydoğusunda bulunan büyük bir evdir. İmparator Augustus döneminde yapılan evin, daha sonra M.S. 94 ve M.S. 115 yıllarında üst üste yeniden inşa edildiği düşünülmektedir. Avlu etrafinda yer alan iç içe geçmiş odalardan oluşan yapı, merkezi bir plana sahiptir. Kuzeydeki giriş holünden sonra triclinium (üç tarafı sedirle çevrili masanın bulunduğu yemek odası) vardır. Bu villada evin en önemli yeri peristyle avlusudur. Kolonadlı avlu anlamına gelen Peristyle avlu, daha geç dönemde küçültülmüş, kolonlar ikinci defa kullanılmıştır. Bu nedenle kolon aralıklarının farklı olduğu, kuzey tarafında 5, doğu tarafında 3 kolon bulunduğu 
görülmektedir. Avluda bir kuyu bulunan evin duvarları düzgün kesilmiş taştan yapılmıştır. Döşemelerde değişik motiflerle süslü mozaiklerin olduğu görülmüştür (Şekil 4) (Usman, 1958).

2 numaralı Roma Evi, Harbiye (Daphne) bölgesinde, Menander Evi denilen, büyük bir komplekstir. Eklemelerle birkaç evden oluşan yapı, M.S. II yüzyıl ve M.S. VI yüzyıl arasında yapılmış ve çok sayıda tadilat gördüğü anlaşılmıştır. En geç dönem yapıldığı düşünülen ortadaki büyük havuz tuğladan inşa edilmiş ve yapım sırasında etrafındaki duvarlarda da değişiklik yapıldığı belirlenmiştir. Menander Evi'nde de avlular ve tricliniumlar bulunmaktadır. Odaların döşemelerinde değişik figürlü mozaikler bulunmuştur (Şekil 5) (Kondoleon, 2001) (Usman, 1958).

3 numaralı plan, Daphne'de bulunan 'Psyche's Ship evidir. Kuzeydeki dar alandan girilir ve girişin karşısındaki oda, kolonlu bir galeriye açılan triclinium' dur. Galerinin güneyindeki duvarda 5 tane niş vardır. Burada yunus figürlerinin bulunduğu bir su havuzu (nympheion) bulunmaktadır. Planlama yine merkezi bir mekan kurgusuna sahiptir. Bu villaya ait başka odalar olduğu düşünülmektedir, ancak günümüze bu kadarı gelmiştir. Odaların döşemesindeki mozaiklere göre villa M.S.II ve III yüzyıldan kalmadır. (Şekil 6)
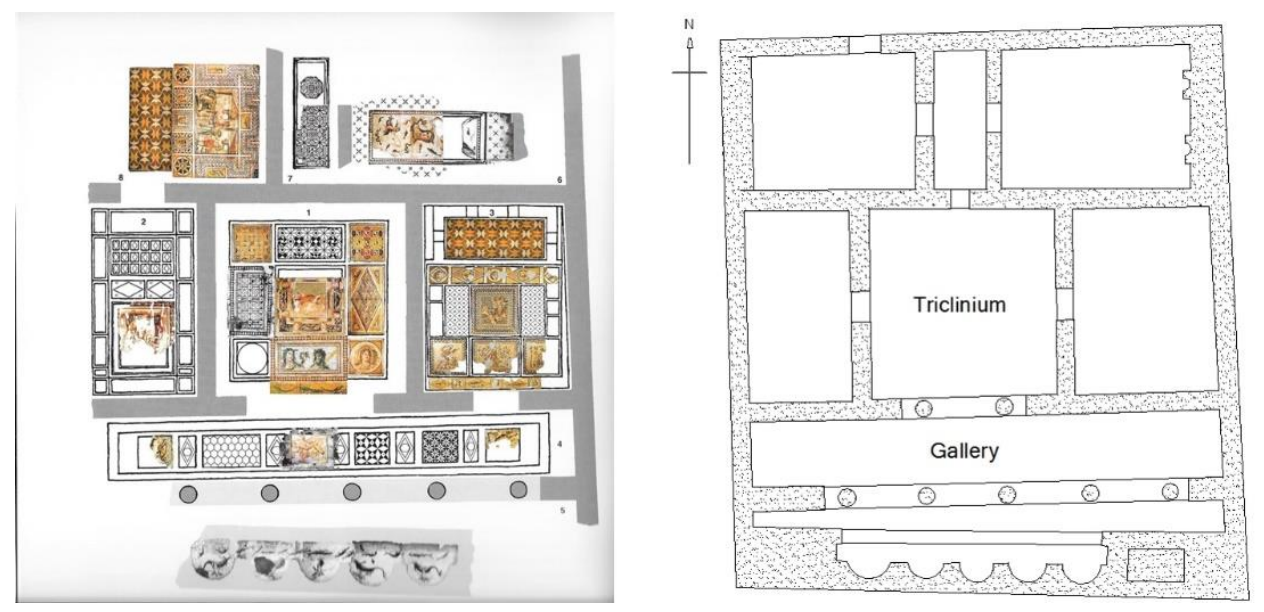

Şekil 6. 3 Numaralı Psyche’s Ship Evi Plan Şeması ve Döşeme Mozaikleri (Kondoleon, 2001)

Roma Dönemi konut yapıları, kazılardan elde edilen sonuçlar ve plan tipleri üzerinden yeniden okunarak, döneme ait mekânsal kurgu, yapı elemanları ve yapı malzemesi gibi mimari özellikler belirlenmiştir. Roma villalarında mekansal kurgu içe dönük, merkezi planlamadır. Peristyle (kolonadlı avlu) avlulu plan tipi görülmüştür. Diş duvarlarda pencereye rastlanmamıştır. Peristyle avlu, evin en önemli yeri olarak kullanılmış ancak geç Antik devirde peristyle avlu önemini kaybetmeye başlamıştır. Avlu içinde kolonadlar, havuzlar ve nymphaionlarla (çeşme) manzara oluşturulmuştur. Evlerin en önemli kısmı sayılan Tricliniumlar (yemek odası) genellikle güneye açılmakla birlikte, evlerde belirgin bir yönlenme yoktur. Ana girişler koridor veya hol biçimindedir. Duvarlar, düzgün kesilmiş dikdörtgen blok taşların üstüste konulmasıyla inşa edilen, tek sıra taş duvardır. Bazı villalarda duvar mozaikleri de bulunmuştur. Döşemelerde çeşitli figürleri içeren mozaikler kullanılmıştır. Mekanın işlevine, konut sahibinin mesleği veya özelliklerine göre mozaik motifleri değişiklik göstermektedir. Roma villalarında kemerlere ve beşik tonozla örtülü salonlara rastlanmıştır. Bölgede elde edilmesi kolay olan ve yöreye ait olan taş ve ahşap kullanıldığı görülmüştür.

\section{Osmanlı Dönemi’nde Antakya Kenti}

Antakya kenti, Osmanlı Devleti yönetiminde olduğu dönemde, gerek kentsel yapıda gerekse bina ölçeğinde bazı değişime uğrayarak, döneminin getirdiği koşullar çerçevesinde, geleneksel Osmanlı şehirleri gibi gelişmiştir. Toplumsal çevre yapısı, mimaride kendini göstermeye başlamıştır. Kentin sokaklarında, meydanlarda ve geleneksel konut mimarisinde bu izleri görmek mümkündür. Bu dönemdeki yapıların büyük çoğunluğu hala kullanılmaktadır. Fonksiyonel eskimeye uğrayan geleneksel eski doku, kafe, lokanta, butik otel gibi işlevsel değişikliklerle kentin odak noktası olma yolundadır (Şekil 7). Ancak konut işlevinden dönüşen bu yapılara değerini kaybetmeden doğru zamanda ve doğru müdahalelerin yapılması, eski dokuya gelecek zararları önleyecektir. 

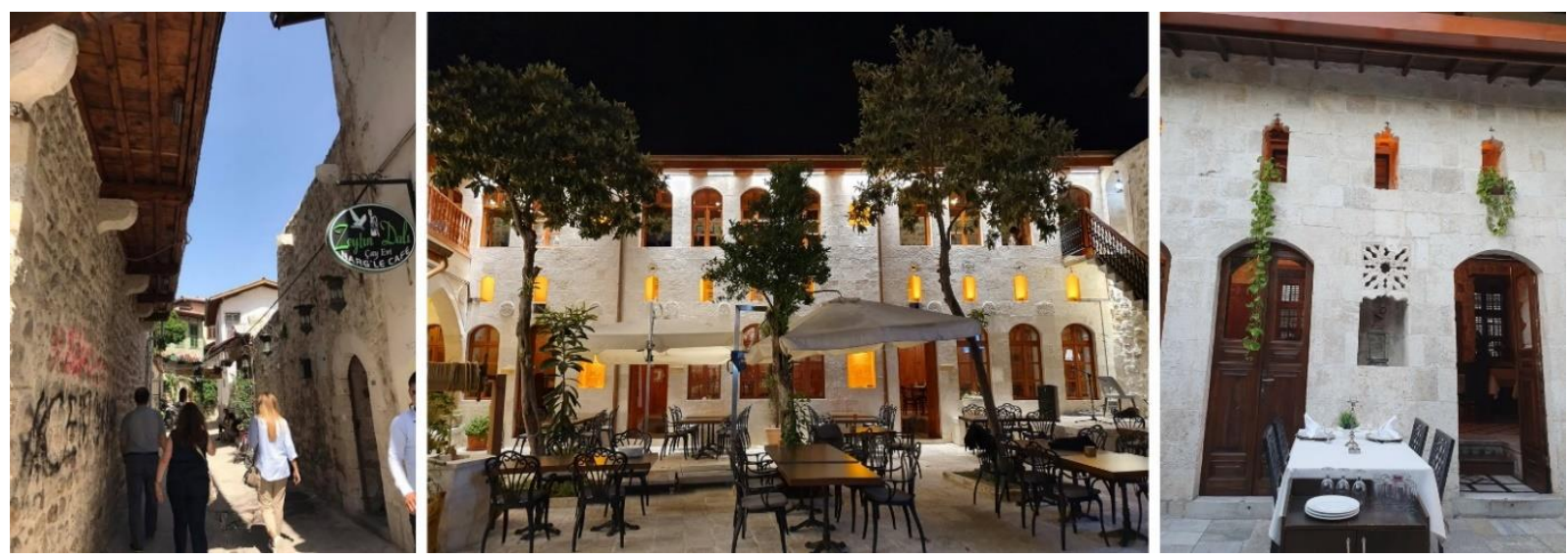

Şekil 7. Eski Dokudaki Konutlar, Lokanta, Otel, Kafe İşlevlerine Dönüşmektedir. (Ş: Yüksel Arşivi)

\subsection{Kentsel Mekan Kurgusu}

Antakya'nın kentsel gelişimi için Hatice Pamir şu yorumu yapmıştır. "Helenistik dönem sonrası uzun bir tarihsel sürecin birikimi olarak Antakya' da şehirleşme olgusu, fiziksel koşulların fazla değişkenlik göstermemesine karşın, değiş̧en sosyal, siyasi, ekonomik koşullara ve teknolojik buluş ve yeniliklere göre değişim göstermiş, yeniden yorumlanmış ve form kazanmıştı" (Pamir, Hatice. 2009) Gerçekten de bu dönemde Antakya Kenti Osmanlı kentlerindeki biçimlenişine uygun olarak gelişmeye başlamıştır. Kentin Roma dönemindeki ızgara planındaki birbirine dik olan sokaklar, daha organik, daha grift bir hale gelmiş ve bitişik yapı düzeni gelişmiştir (Şekil 8).

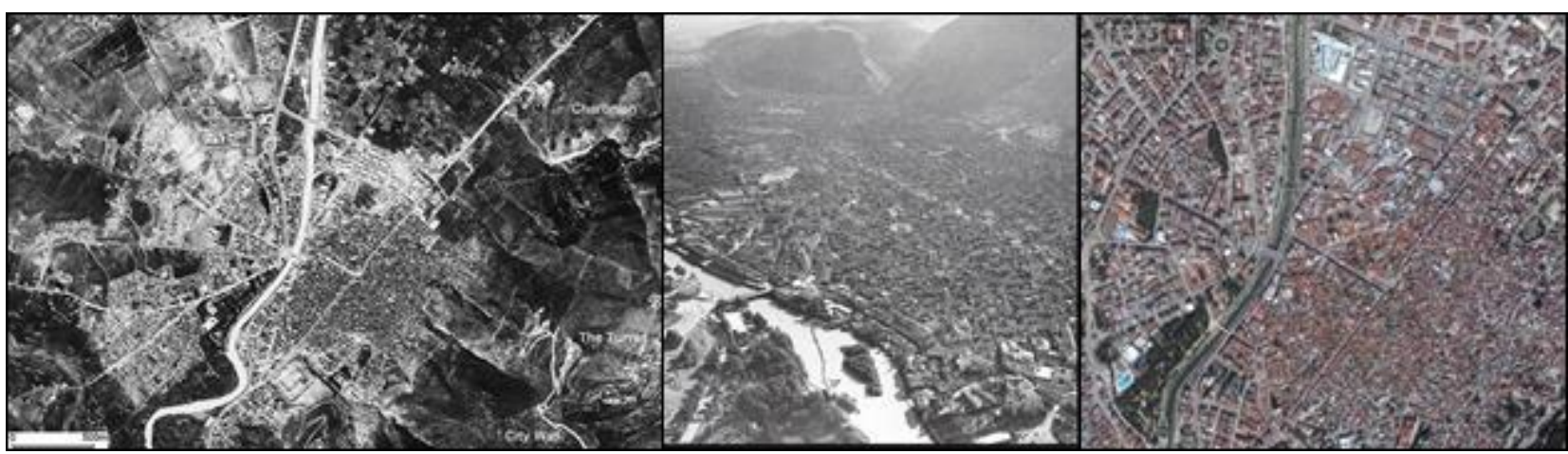

Şekil 8. Antakya Kenti, 1969 yılı (Demir, 1996) - 1930 yılı (Kondoleon) - 2020 y1lı (https://maps.google.com.tr)

Bitişik nizam avlulu evlerin arasında kalan, iklimin etkisiyle, sıcaktan korunmak amaçlı dar sokaklar, Asi nehrine dik olarak açılır ve hakim rüzgarı içlerine alır. Sokakların malzemesi yöreden çıkarılan doğal blok taş döşemedir ve fazla yağı̧̧ alan kentin sokakları bu malzeme sayesinde hemen kurur ve çamur olmaz.

Sokakların arasında çıkmaz sokak denilen üç veya daha fazla sayıda evin girişinin olduğu, devamı olmayan sokaklar bulunmaktadır. Döneminde bu sokaklar, çocukların oynayabileceği, büyüklerin kapı önünde oturup sohbet edebileceği kamusal alan olarak sosyalleşme amaçlı kullanılmaktaydı. Günümüzde çıkmaz sokakların çoğu, yıkılmış olan evler nedeniyle özelliklerini kaybetmişlerdir.

\subsection{Mimari Mekan Kurgusu}

Genellikle iki katlı olan evler, kare veya dikdörtgen biçimindeki bir avlu çevresine dizilmiş mekanlardan oluşan, içe dönük, merkezi bir planlamaya sahiptir. Evlerde belirgin bir yönlenme yoktur, ancak iki veya üç tarafı odalarla çevrili evlerde, yaşantıda yazlık ve kışlık odalar olmak üzere bir ayırım vardır. Sokak kapıları genellikle kemerli, önünde 40 - $50 \mathrm{~cm}$ yüksekliğinde eşik taşı bulunan büyük kapılardır. Malzeme olarak ahşap veya demir kullanılmıştır. Sokak kapısı ile avlu arasında geçişi sağlayan üstü kapalı "aralık" denilen bir koridor vardır, buradan ikinci bir kapıyla avluya ulaşılır.

Evin ana mekanı olan ve günlük yaşantının büyük bir bölümünün içinde geçirildiği avlu, dışarıya karşı yüksek ve sağır duvarlarla kapanmıştır. Genellikle avlularda iklimsel nedenlerden dolayı havuz ve kuyu bulunur. Büyüklüğüyle 
orantılı olarak, serinlik yaratması açısından avlulara yörenin ağaçlarından portakal, hurma, nar, defne ağaçları dikilmiştir. Odalar, avluya açılarak ışığı buradan alırlar. Kesme taştan yapılmış avlu duvarındaki dar kapı ve pencere boşlukları, odalar ile avlu arasındaki ilişkiyi kurar. Pencereler üzerinde farklı motifleri içeren taş oymalarla süslenmiş, doğal havalandırmayı sağlayan kafa pencereleri bulunur. Evlerin malzemesi, taş ve ahşaptır. Yöreden çıarılan taş ve ahşap, nemli iklime sahip olan kent için uygun malzemedir. Avlu duvarları, ve avlu döşemesi bu taşla kaplıdır. Alaturka kiremitle kaplı çatılar iki tarafa eğimli kırma çatılardır (Şekil 9 - 12)

Antakya Kenti mimarisinde, değişik kültürlerin etkilerini görmek mümkündür. Osmanlı döneminde yapılan geleneksel konutların yanı sıra, Fransız yönetimindeyken, inşa edilen yapılarda, farklı mimari etkiler görülmektedir. Daha çok kamu ve yönetim binası olarak inşa edilmiş olması nedeniyle çalışmada, Osmanlı Dönemi geleneksel konutları değerlendirmeye alınmıştır.
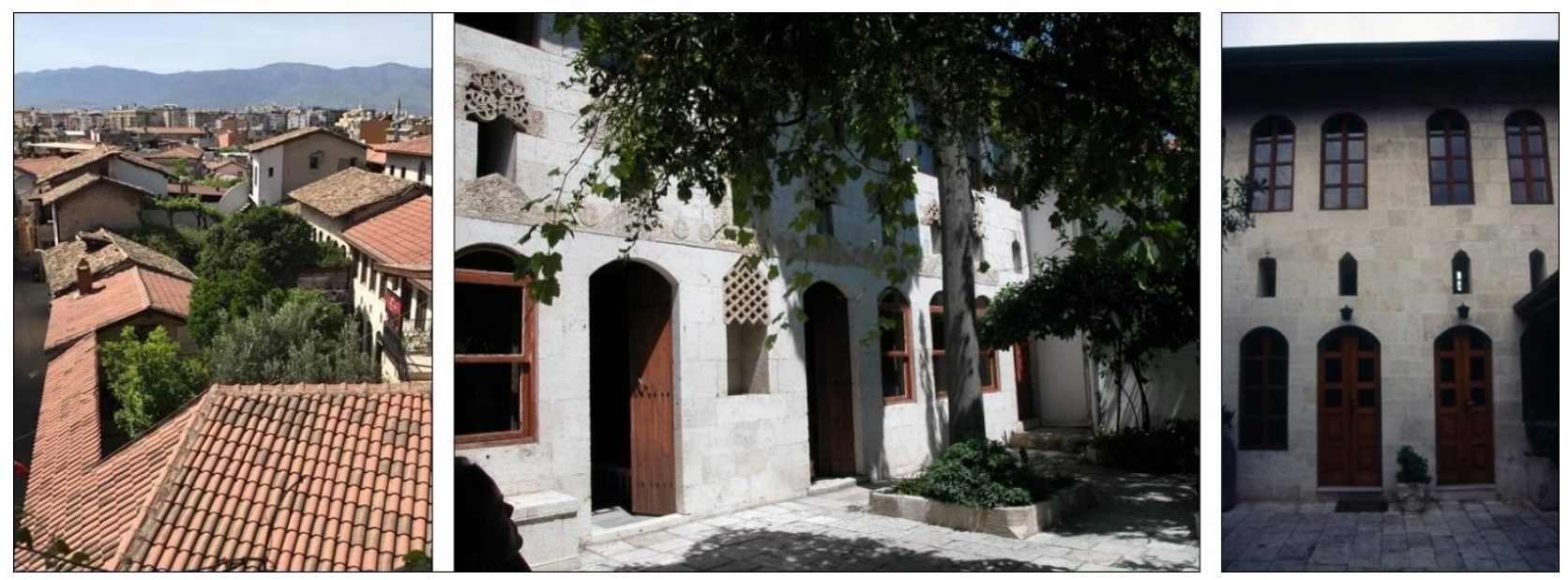

Şekil 9. Osmanlı Dönemi Konut Mimarisi, çatı ve avlu içlerinden görünüm (Ş.Yüksel Arşivi).
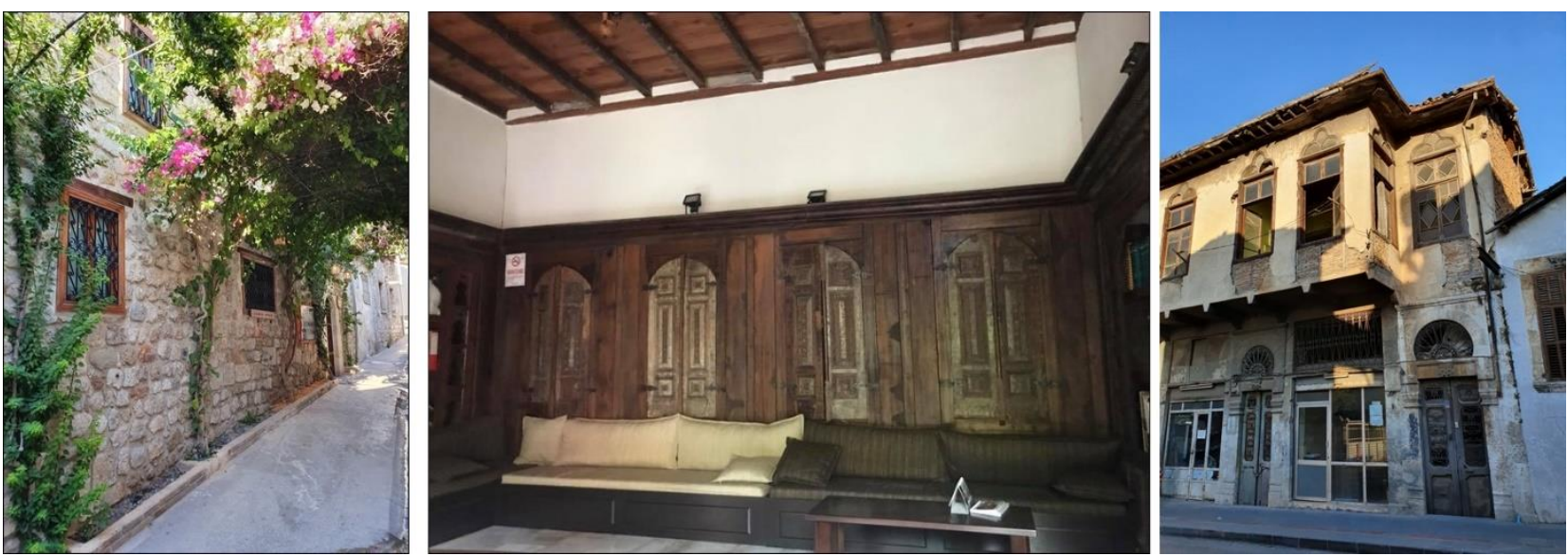

Şekil 10. Osmanlı Dönemi Konut Mimarisi, iç-dış görünümler (Ş. Yüksel Arşivi). 

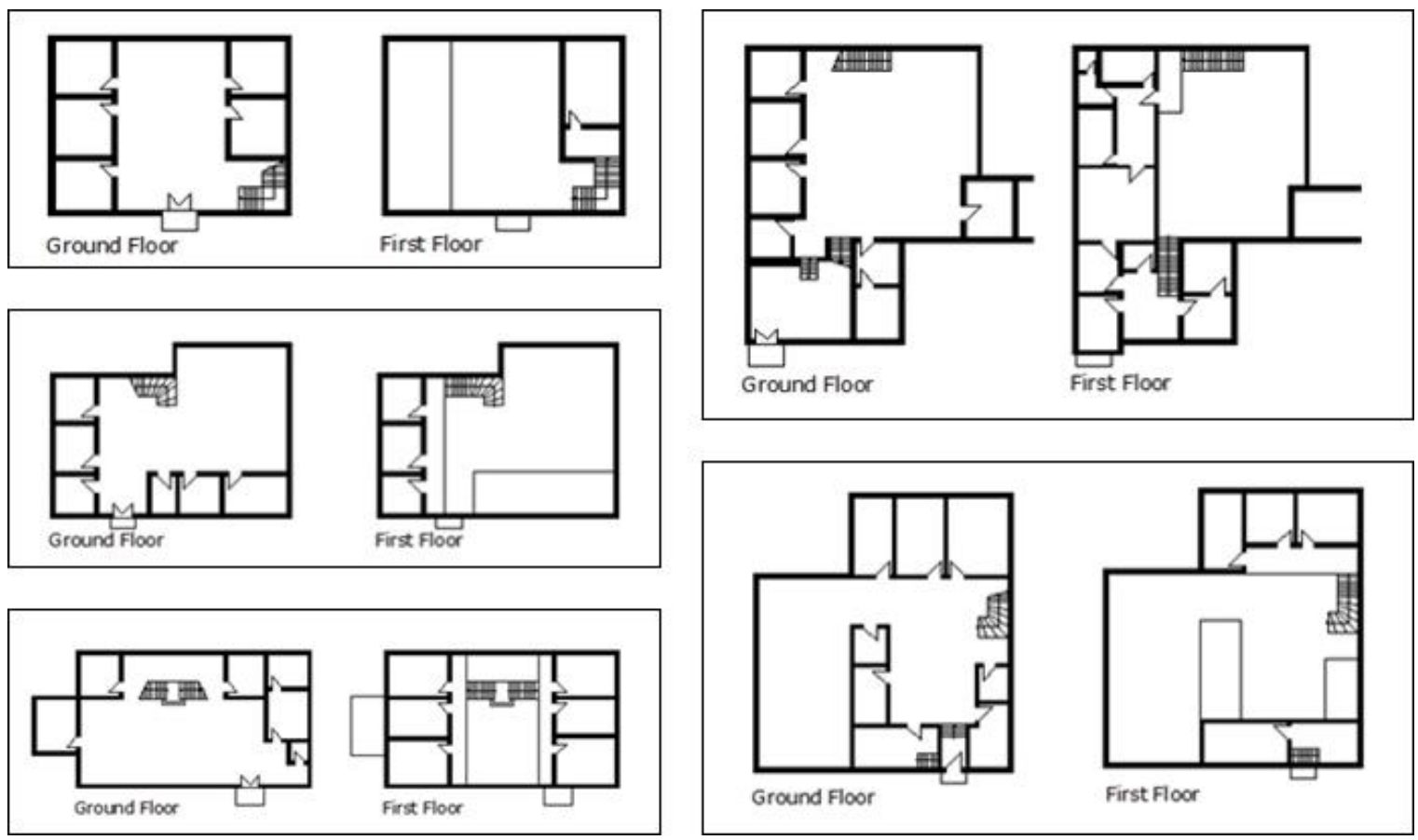

Şekil 11. Antakya Kenti Osmanlı Dönemi yerel konut plan tipolojileri. (Yazar tarafından oluşturulmuştur.)

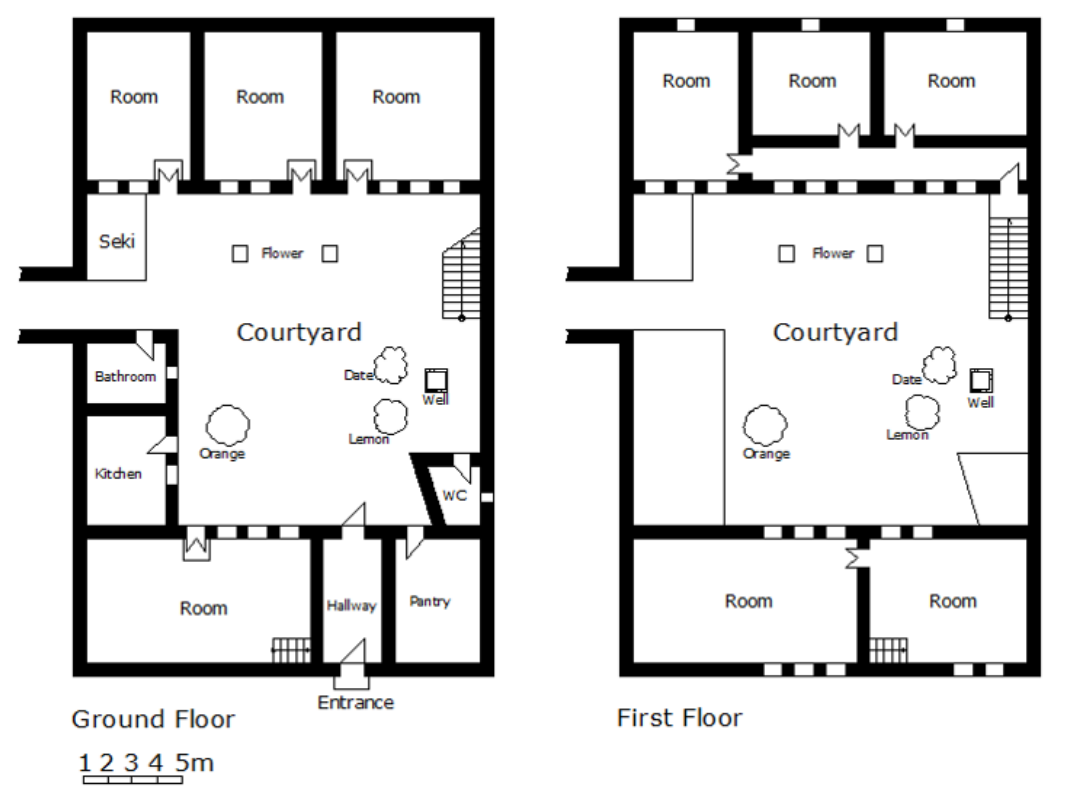

Şekil 12. Üç tarafı odalarla çevrili plan tipi şeması (Dudu- Hüsnü Melek Evi Plan Şeması, yazar tarafindan oluşturulmuştur.) 


\section{Antakya Kentinin Günümüzdeki Durumu}

Antakya, günümüze kadar tarihi katmanların izlerini korumuş, kimlik ögeleri güçlü bir kenttir. Kentte, 1933 yllında onaylanan imar planı ile büyük caddeler ve bağlantı yolları açılmışıı. Eski doku kenarında açılan Kurtuluş Caddesi ve ona bağlanan caddeler üzerinde inşa edilen binalar bu dönemde yapılmıştır. Köprü başı düzenlemesi de 1933 imar planında önerilmiştir. Bu dönemdeki tasarımlar, tarihi dokuya ve sürekliliğe fazla zarar vermemiştir. Ancak 1957 tarihli İmar Planı, eski kent dokusu üzerinde köklü değişikliklere neden olmuş, katlı konut yapımına başlanmış, geniş bulvar ve yollar açılmıştır (Demir, 2005). Kentte apartmanlaşma olgusunun başlaması sosyal çevreyi etkilemiş, apartmanların tercih edilmesiyle, 19. yy Osmanlı yerel konutları, sahipleri tarafindan terkedilerek fonksiyonel eskimeye uğramıştır. Evler, kırsaldan göç edenlerin kullanımına bırakılmış, konut dışında imalathane ve depo olarak kullanılmaya başlamıştır. Küreselleşme ve moderleşme kavramları, her yerde olduğu gibi Antakya'da da kültürel ve mekânsal birikimden uzak yapıların oluşmasına neden olmuştur. 1987 Koruma İmar Planı ile tarihi doku için önlemler alınmak istenmiştir. Eski kent dokusu günümüzde dönüşüme uğrayarak varlığını sürdürürken, nüfus artışıyla birlikte, yeni tasarımlar "yer"siz ve kimliksiz yapılar halinde inşa edilmekte ve kent giderek özelliklerini kaybetmektedir. İlk apartman örnekleri, kentsel dönüşüm kapsamında yıkılarak, 7 kat halinde inşa edilmektedir. Bu durum, korunmuş tarihi dokuya da zarar verecektir. Kentin yeni halini sorgulamak ve önlem almak gerekmektedir. Bu yapılar kent kimliğine katkı sağlıyor mu? Bulunduğu yere ait mi? Yeni tasarımlar çevreye saygılı mı? Eski yapı kullanılırken kimliğini koruyor mu? Eski kent dokusuna yapılan müdahaleler sağlıklı mı? gibi soruların sorulması ve çözüm arayışına gidilmesi kent için yapılması gereken çalışmalardandır.
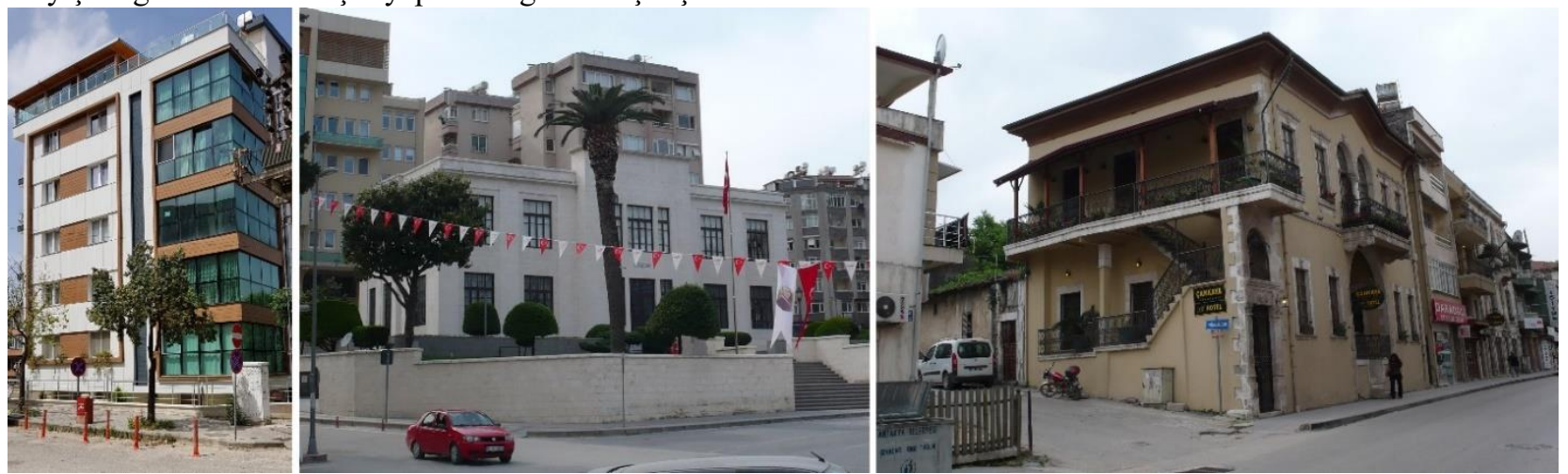

Şekil 13. Antakya Kenti günümüzden fotoğraflar (Ş:Yüksel Arşivi)

\section{Bulgular}

Tarihsel süreçte Antakya'da, çeşitli uygarlıkların yaşaması, kentin zengin kültürel birikime sahip olmasına neden olmuştur. Tüm kentlerimizde olduğu gibi Antakya kentinde de, apartmanlaşma sürecinin başladığı yıllarda bozulmalar baş göstermiş, kentin tarihi dokusu ihmal edilmeye başlamıştır. Ancak günümüzde, küresel gelişme, bilinçsiz planlama ve uygulamalar, artan kırsal göç gibi nedenler, kente ait olmayan yapılaşmayı ve bozulmayı daha da arttırmaktadır. İlk apartmanlaşmanın olduğu 1960 ve 1970 li yıllarda yapılan 5 katlı konutlar, kentsel dönüşüm kapsamında yıkılarak, yerine daha sıkışık 7, 8 katlı, giydirme cepheli apartmanlar yapılmaktadır. Kimliği yansıtmayan, çevresel ve bölgesel koşullara uymayan yapıların artması, kültürel değerlerin giderek kaybolmasına ve yaşam kalitesinin düşmesine neden olmaktadır.

Antakya Kentinin iki farklı katmanındaki kentsel ve mimari kurgu üzerinden yapılan çalışmalar sonucunda elde edilen bulgular karşılaştırıldığında benzerlikler olduğu görülmüştür. Benzerlikler fiziksel çevre koşullarına göre toplumsal çevrenin, kentin biçimlenişine katkısı sonucunda ortaya çıkmıştır. Başka bir deyişle, bu iki tarihsel dönem farklı kültürde olsalar bile, aynı fiziksel çevre özelliklerine sahip oldukları için, konut biçimlenişlerinde benzerlikler bulunmuştur (Tablo 2,3). Günümüze kadar, katmanlar arası sürekliliğin devam ettiğini söylemek mümkünken, bugün kentin sürekliliğinin devam ettiğini söylemek zordur. Değişim ve gelişim olması gereken bir süreçtir ancak değişimler sürekliliği sağlamaya yönelik adımlarla yapıldığında amacına ulaşabilir. Karşılaştırma sonucunda ortaya konan benzerliklerin aynısını yapmak değil, neden ve nasıl yapıldıklarını sorgulayarak felsefesini yorumlamak çözümdür. Benzerliklerin yorumlanarak, gerekirse revize edilerek, bugünkü teknolojiyle gereksinimlere cevap verecek biçimde uygulanması, Antakya kenti için yaşam kalitesini arttıracak ve sürekliliği sağlayacaktır. 
Tablo 2. Kentsel Mekan Kurgusu üzerinden karşılaştırma

\begin{tabular}{|l|l|}
\hline ROMA DÖNEMI KENTSEL MEKAN KURGUSU & OSMANLI DÖNEMI KENTSEL MEKAN KURGUSU \\
\hline $\begin{array}{l}\text { Kent Hippodamus'un ilkeleri doğrultusunda birbirini dik kesen } \\
\text { 1zgara plan tipinde inşa edilmiştir }\end{array}$ & $\begin{array}{l}\text { Izgara Plan tipi bozulmaya başlamış, dönemin etkisiyle organik } \\
\text { biçime dönüşmüş, dar girift sokaklar gelişmiştir. }\end{array}$ \\
\hline Sokaklar Asi nehrine dik olarak yönlenmiştir. & Sokaklar Asi nehrine yönlenmiştir. \\
\hline $\begin{array}{l}\text { Kenti kuzeydoğu-güneybatı doğrultusunda kesen kolonadlı, } \\
\text { mermer kaplı bir cadde olduğu anlaşılmıştır. }\end{array}$ & $\begin{array}{l}\text { Aynı caddenin yerinde Kurtuluş caddesi adıyla bir cadde } \\
\text { bulunmaktadır. }\end{array}$ \\
\hline Evler bitişik ve iç içe yerleşmiştir. & Evler bitişik nizam şeklinde gelişmiştir. \\
\hline
\end{tabular}

Tablo 3. Mimari Mekan Kurgusu Üzerinden Karşılaştırma

\begin{tabular}{|c|c|c|c|}
\hline & MEKANSAL KURGU & YAPI ELEMANLARI & YAPI MALZEMESİ \\
\hline 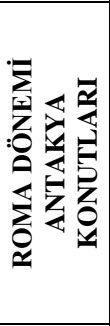 & $\begin{array}{l}\text {-Avlulu ev planları } \\
\text {-İce dönük, merkezi planlama } \\
\text {-Evler bitişik veya iç içe } \\
\text {-Evlerde belirgin bir yönlenme yoktur. } \\
\text {-Tricliniumlar (yemek odası) genellikle } \\
\text { güneye açılırlar } \\
\text {-Girişler koridor veya hol } \\
\text { biçimindedir. } \\
\text {-Avluda, kolonadlar, havuzlar ve } \\
\text { nympheionlar bulunur }\end{array}$ & $\begin{array}{l}\text {-Duvarlar, taş duvardır. } \\
\text {-Pencereler avlu cephelerinde yer } \\
\text { almaktadır. } \\
\text {-Döşemelerde çeşitli figürleri içeren } \\
\text { mozaikler kullanılmıştır. } \\
\text {-Kemerle örtülü açıklıklar ve beşik } \\
\text { tonozla örtülü salonlar görülmüştür. }\end{array}$ & $\begin{array}{l}\text {-Duvarlarda taş ve ahşap kullanıldığı } \\
\text { görülmüştür. } \\
\text {-Evlerin zemininde çeşitli figürlerin } \\
\text { anlatıldığı mozaik kaplamalar } \\
\text { bulunmuştur. } \\
\text {-Bulgular ahşap ve kiremit } \\
\text { kullanıldığını göstermektedir. }\end{array}$ \\
\hline 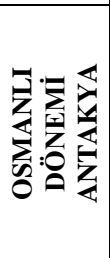 & $\begin{array}{l}\text {-Avlulu ev planları } \\
\text {-İçe dönük, merkezi planlama } \\
\text {-Bitişik nizam yerleşim } \\
\text {-Evlerde belirgin bir yönlenme yoktur. } \\
\text {-Evlere aralık denilen bir koridordan } \\
\text { girilir. } \\
\text {-Avluda havuz, ağaç ve çeşme vardır. }\end{array}$ & $\begin{array}{l}\text {-Duvarlar, taş veya ahşaptır. } \\
\text {-Pencereler avluya açılır. } \\
\text {-Döşemeler ahşap ve taştır. } \\
\text {-Çatılar kırma çatıdır. Avluların üzeri } \\
\text { açıktır. }\end{array}$ & $\begin{array}{l}\text {-Duvarlarda taş ve ahşap kullanıldığı } \\
\text { görülmüştür. } \\
\text {-Odaların döşeme kaplamaları karo } \\
\text { mozaik veya ahşaptır. } \\
\text { Avlu zemininde ise kesme taş } \\
\text { kullanılmıştır. } \\
\text {-Çatı malzemesi olarak ahşap ve } \\
\text { kiremit kullanılmıștır. }\end{array}$ \\
\hline
\end{tabular}

Karşılaştırma sonucunda, her iki dönem için kentsel kurgu üzerinden okuma yapıldığında, aşağıda bulgulara ulaşılmıştır:

- Sokakların, Roma Döneminde dik, Osmanlı Döneminde, dönemin biçimsel özelliklerine göre daha organik hale gelse de yine, Asi Nehri'ne açık olduklarını görmekteyiz. Nedeni; İklim nedeniyle bol yağış alan kentin, dağdan gelecek yağmur sularının, kente zarar vermeden nehire ulaşmasını sağlamaktır. Ayrıca sudan gelecek esintiler de, iklim nedeniyle, rüzgarın istendiği kentte sokakları serinleterek doğal havalandırma kanalı görevini yapmışlardır.

- Binaların her iki dönemde de bitişik ve iç içe olması, sokakların dar olmasına neden olmakta, yine iklim nedeniyle sokaklarda istenmeyen güneşi engelleyerek gölge alanlar yaratmaktadır.

- Kentin kuzeydoğu-güneybatı doğrultusundaki hakim rüzgarı alan, eski dokuyu boydan boya kesen uzun cadde, iki tarihsel katmanda da üstüstedir. Roma Dönemindeki adı Herod olan Kurtuluş Caddesi için günümüzde, $9 \mathrm{~m}$ alttaki katmana ulaşarak bir yürüyüş alanı planlanmaktadır. Bu çalışmanın, kente kültürel değer katarak, olumlu sonçlara yol açması temenni edilmektedir.

Karşılaştırmada mimari mekan kurgusu üzerinden okuma yapıldığında ise aşağıdaki sonuçlara ulaşılmıştır :

- Evler, her iki dönemde de avlu etrafına dizili odalardan oluşan merkezi planlamaya sahiptir. Büyük açık alana sahip olan evler, az katlıdır. Osmanlı Dönemi yerel konutları iki katlı, altı çarşı olan tiplerde ise zemin kat dükkan, üst kat konut şeklindedir. Nedeni ; iklimsel koşullar dış mekan ihtiyacını arttırmakta, kentin sahip olduğu yerel rüzgarlar nemi dağıtarak, açık alanlarda konforu sağlamaktadır. Osmanlı Dönemi Konutlarında bu nedenle avluya Hayat da denilmiştir. Kent 1. Derece deprem bölgesidir ve tarihsel süreçte, çok sayıda depremle kent büyük zararlar görmüştür. Az katlı binalar, bu zararları azaltmaktadır. 
- Pencere ve kapılar, küçük ve her iki dönemde de iç avluya yöneliktir. Sıcak ve soğuk iklim bölgelerinde cepheye açılan küçük açıklıklar, iç mekanlarda istenilen 1sı derecesine ulaşmayı doğal yollardan sağlamaktadır.

- Çatılar, Roma dönemi'nde fazla veriye ulşılamadı̆̆ından net bir sonuca varılmamakla birlikte kazılardaki buluntularda ahşap ve kiremit olması, Osmanlı Dönemi’nde olduğu gibi kırma, ahşap ve kiremit çatıyı düşündürebilir. Fazla yağış alan kentin Osmanlı evlerindeki kırma çatılar dar sokakların da üzerini örterek yayaları korur ve yağmur sularını sokakların ortasına yönlendirir. Sokağın ortasındaki ark denilen oluklardan giden yağmur suları AsiNehri’ne dökülür. Çatı ve sokaklar drenaj görevini üstlenmişlerdir.

- Malzeme, bölgeden çıkarılan taş ve ahşaptır. Roma Dönemi’nin mozaikleri evlerin döşeme ve duvarlarını kaplamıştır. Osmanlı Dönemi evlerinde döşemede kullanılan karo taşların desenleri yöreye özgüdür. Duvar ve döşemelerde kullanılan yore taşları, iç mekanları kışın sıcak yazın da serin tutmaktadır.

\section{SONUÇ :}

Tarihsel süreçte mimari oluşumların, kentsel ve bina ölçeğinde, çevresel koşullara göre biçimlendiği bilinen bir gerçektir. Her bina, çevrenin bir parçası olarak kültürel ve fiziksel bağlamıyla birlikte var olabilir. Geçmişinden gelen referanslara sahip olduğunda kimliğini sürdürebilir. Antakya Kenti’nin farklı katmanları karşılaştırıldığında da bu gerçekliğe ulaşılmış ve her iki katmanda da ortaklıkların devam etmesi, sürekliliği de beraberinde getirmiştir. Konut bazında ele alınan çalışma, apartmanlaşma sürecine kadar yoğun bir sürekliliğin olduğunu, sonradan kesintiye uğradığını göstermiştir. Bulgulardaki mekansal sürekliliği sağladığı belirlenen kriterler, günümüzde de yorumlanarak devam ettirilebilir. Açık alan ihtiyacı, yerel ve iklime uygun malzeme gibi kriterler gerçekleştirilebilir.

Sonuç olarak Antakya Kenti için, karşılaştırmadan elde edilen yerel bulgular uyarlanabilir ve aşağıdaki öneriler geliştirilebilir.

- Kent planlaması, kentin çevresel koşullarına göre yapılmalı, kontrolsüz gelişimler önlenmelidir. Üst ölçekte çevresel koşullar düşünülerek planlamanın eksiksiz yapılması sorunları önleyecektir.

- Günümüzde yapılan bina tasarımlarında da çevresel koşullar düşünülmelidir. Özellikle konut binaları, çok katlı olmamalı ve cephe yüzeylerinde enerji tüketimini arttıracak tasarımlardan kaçınılmalıdır. Kent ve bina ölçeğindeki tasarımlar, mekansal sürekliliği devam ettirecek şekilde, katmanlararası belirlenen ortaklıklar uyarlanarak yapılabilir. Yeni tasarımlarda, balkon, teras gibi açık alanların olmayışı veya ölçeksiz olması yaşam kalitesini düşürecektir. Doğru seçimlerle, minimum enerji harcayarak maksimum konfor elde edilebilir.

- Eski dokudaki tarihi binaların işlev değiştirirken zarar görmemesi için bilinçli yaklaşımlar benimsenmelidir.

- Kentin sahip olduğu doğal ve kültürel potansiyeller değerlendirilerek; kentin özgün kimliğine katkısı bulunan ve ait olduğu döneme ilişkin veriler taşıyan yapıların korunması, yeni tasarımlarda geçmişle gelecek arasındaki bağın devam etmesi, kültürel sürekliliğin sağlanmasında ve kimliğin geleceğe taşınmasında önemli rol oynayacaktır.

\section{Etik Standart ile Uyumluluk}

Çıkar Çatışması: Yazar herhangi bir çıkar çatışmasının olmadığını beyan eder.

Etik Kurul İzni: Bu çalışma için etik kurul iznine gerek yoktur.

Finansal Destek: Yoktur. 


\section{KAYNAKÇA}

Akı, A., Yüksel, Ş. (1999) . Anadolu Yerleşim Dokusu İçinde Antakya Kentinin Çevresel ve Bölgesel Koşullar İçinde İrdelenmesi. Settlement and Housing in Anatolia Through the Ages, Institute of Archaelogy, Ege Yayınları, Istanbul.

Apaydın, B. (2019). Palimpsest Kavramı Ve Mekansal Dönüşüm. The Turkish Online Journal of Design, Art and Communication, Volume 9, Issue 2. Açık Erişim.

Ballantyne, A. (2014). Mimarlar için Deleuze ve Guattari, YEM Yayınları, İstanbul.

Çalışır, Hovardaoğlu, S. (2009). Tarihi Süreklilikte Kentsel Katmanlaşmanın Belgelenmesi Bağlamında Kayseri Kent Merkezi. Doktora Tezi, İstanbul: İstanbul Teknik Üniversitesi, Fen Bilimleri Enstitüsü, Mimarlık Anabilim Dalı, Restorasyon Bilim Dalı.

Demir; A. (1996). Çağlar İçinde Antakya, Akbank Yayınları, İstanbul.

Demir, A. (2005). "Kültürlerin Ortak Kenti ve Ortak Mimarlıklar" Konuşmalar Bildiriler Değerlendirmeler AdanaAntakya Bildirgesi. UIA XXII. Dünya Mimarlık Kongresi, Mimarlar Odası Yayını, İstanbul.

Gür, Ö. Ş. (2017). Sans Lieu Ya da Yeri Yaratmak, Beykent Üniversitesi, Müh.Mim.Fak. 20. Y1l Etkinlikleri, Beykent Üniversitesi Yayınları, İstanbul.

Kondoleon, C. (2001). Antioch The Lost Ancient City, Princeton University Press, Princeton.

Manning, J., Rifkin, A., Elsea, D., Eid, L., Garofalakis, G. (2020). Complex city, London's changing character, ebook, Riba Yayınc1lik, London.

Massey, D. (2001). Space, Place and Gender, University of Minnesota Press, Minneapolis.

Nakip, B. (2012). Eski Antakya'dan Görünümler, Tarihsel Yapılar ve Ünlü Yerler, Antakya Belediyesi Kültür Yayınları, Antakya.

Norberg-S. C. (1984). Genius Loci: Towards a Phenomenology of Architecture, Rizolli, NY.

Pamir, H. (2014) “Antakya ve Çevresindeki Arkeolojik Araştırmala:2001-12" Antioch On The Orontes/ Asi'deki Antakya. Der. Redford, S. Koç Üniversitesi Yayınları, s.79-127. İstanbul

Pamir, H. (2009). Alalakh'dan Antıokheı'ya Hatay'da Kentleşme Süreci, Mustafa Kemal Üniversitesi Sosyal Bilimler Enstitüsü Dergisi, Y1l: 2009, Cilt: 6 Sayı: 12, Antakya.

Redford, S. (2014). Antioch On The Orontes/ Asi’deki Antakya, Koç Üniversitesi Yayınları, İstanbul.

Tanyeli, U. (2017). Yıkarak Yapmak. Anarşist bir Mimarlık Kuramı İçin Altlık, Metis Yayınları, İstanbul.

Usman, M. (1958). Antik Devir Küçük Asya Evleri, Istanbul Teknik Universitesi, İstanbul. 